\title{
Prihodnost izobraževanja odraslih v Evropi - inovacije v izobraževanju odraslih in oblike sodelovanja z Evropo
}

\author{
Nena Mijoč
}

Ta prispevek je del raziskovalnega poročila, ki je nastalo na osnovi sodelovanja $\mathrm{v}$ projektu Eurodelphy $\mathrm{z}$ naslovom Prihodnost izobraževanja odrasilh v Evropi. V njem obravnavamo del analize odgovorov, ki smo jih dobili od 86 respondentov, strokovnjakov na področju izobraževanja odraslih v Sloveniji. Natančnejša razlaga metodološkega pristopa in opis vzorca sta podrobneje podana v prispevkih dr. Ane Krajnc in Sabine Jelenc. Naš prispevek obravnava predvsem problematiko inovacij in sodelovanja z Evropo v okviru izobraževanja odraslih.

Inovacije sprožajo spreminjanje in pospešujejo kakovostni razvoj na nekem konkretnem področju. Ljudje ne vstopajo več v kateri koli izobraževalni program, zanima jih predvsem kakovost programa, možnost za aktivno sodelovanje in neposredna uporabnost znanj. Inovacije nastajajo tudi kot posledica večjega pomena, vloženih investicij, dela in časa, ki ga $\vee$ zadnjih letih posvečamo izobraževanju odraslih.

Torsten Husen pravi, da lahko včasih tudi $z$ inovativnimi pristopi $v$ izobraževanju, $\mathrm{z}$ novimi metodami in oblikami vzbudimo motivacijo pri tistih potencialnih udeležencih izobraževanja, ki se sicer ne odločajo za vključitev v izobraževalne programe (Husen, 1974). V primerjavi s šestnajstimi evropskimi deželami, ki so sodelovale v projektu, slovenski strokovnjaki menijo, da smo v zadnjih dveh letih zasledili precej inovacij v izobraževanju odraslih. Kot je razvidno iz naslednje tabele, je Slovenija po inovacijah na tretjem mestu. Več inovacij kot pri nas je bilo, glede na odgovore, le na Portugalskem in v Estoniji (tabela 1). Največ inovacij so v celotnem vzorcu zasledili izobraževalci, komentatorji oziroma novinarji pa so jih opazili bistveno manj.

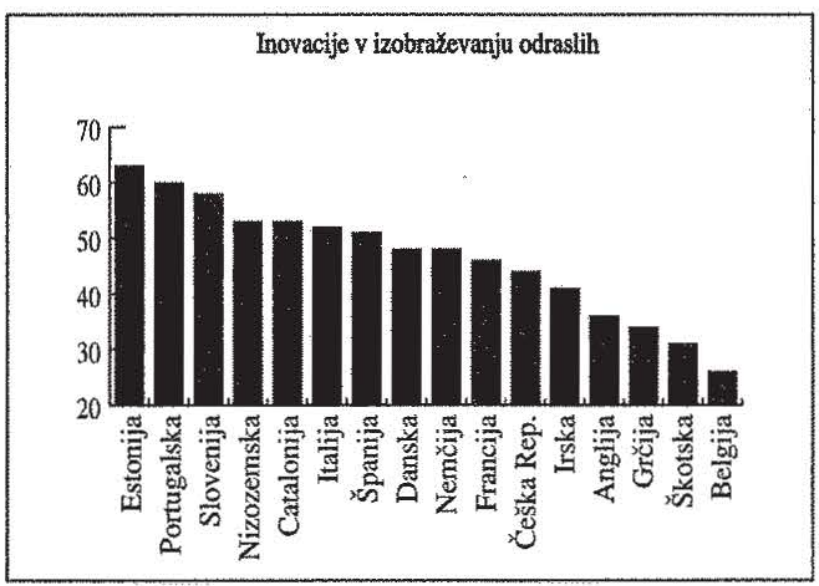

Na katerih področjih izobraževanja odraslih je bilo $v$ zadnjih dveh letih uvedenih največ inovacij?

Sporazumevanje je vsebinsko področje, za katerega je največ anketiranih (v Sloveniji 70,7\%, v celotnem vzorcu EU 61\%) menilo, da so bile $v$ preteklem letu ali dveh uvedene inovacije. $\mathrm{V}$ okviru sporazumevanja se naši odgovori največkrat nanašajo na izobraževalne programe o komuniciranju (22 odgovorov, podrobneje opredeljujejo npr. medosebno komuniciranje, pogajanja, poslušanje, spodbujanje novih idej, sporočanje preko medijev, uporaba prosojnic, NLP), omenjajo pa tudi učenje tujih jezikov, sporočanje o tehnoloških dosežkih, medinštitucionalno sodelovanje in sodelovanje $v$ javnosti.

Inovacije so nastale predvsem zaradi potreb po vključevanju v Evropo, potreb podjetij, vodstva, pomanjkanja teh znanj (7 odg.), spoznanj, da je sodelovanje in učenje drug od drugega nujnost (5 odg.); ugotovitve, da je med brezposelnimi veliko funkcionalno nepismenih; da imamo zastarel način poučevanja; da nas pestijo kriza, spremembe in strah, iz želje, da bi izboljšali delo v šoli, povečali neodvisnost, uspešnost v vsakdanjem sporazumevanju ( 3 odg.) in ne nazadnje zaradi dobre ponudbe izvajalcev ( 2 odg.).

V slovenskem vzorcu sledi po številu inovacij področje razvijanja lastne osebnosti, ki vsebinsko zajema spoznavanje $z$ novimi veščinami, metodami in tehnikami ( 15 odg.), razvoj pozitivnega mišljenja (4 odg.), razvoj profesionalne etike, vplive tuje literature in novih naravoslovnih spoznaj, skrb za kariero (2 odg.).

Omenjene inovacije so po mnenju anketiranih nastale zaradi naše ločenosti od sveta, zaradi stikov s tujci, zaradi želje, da bi spoznanja prenesli na druge, dobre ponudbe literature in izobraževalnih programov, zaradi novih tehnologij, povpraševanja in težnje po reševanju problemov, pa tudi zaradi osebne potrebe po učenju.

$\mathrm{Na}$ tretjem mestu po številu inovacij je uporaba matematicnih in računalniških znanj $(61 \%$ jih meni, da so bile tu uvedene inovacije, za EU velja 52\%), kjer gre najpogosteje za ucenje uporabe osebnega računalnika in ustreznih računalniških programov (21 odg.), pa tudi za učenje računalniških jezikov, matematike in računalništva $\mathrm{v}$ fiziki, za uporabo rezultatov in matematike $\mathrm{v}$ vsakdanjem življenju. Inovacije so bile spodbujene predvsem s potrebami po učinkovitosti, z zahtevami na delu (13 odg.), z razvojem in možnostmi uporabe računalnika (12 odg.), pa tudi zaradi strahu pred neznanjem in potrebo po naglih reakcijah, saj računalnik omogoča natančnost in hitrost.

Opisali smo vsebinska področja, za katera so anketirani menili, da je bilo v zadnjem letu ali dveh uvedenih največ inovacij. Poglejmo še primerjalno tabelo med pomenom, investicijami in inovacijami za celotni vzorec $v$ EU:

Zaskrbljujoče je, da je najmanj inovacij $v$ Sloveniji na področjih, ki jim je tudi pripisan majhen pomen in kjer je malo vloženih investicij in truda, torej pri cilju »sodelovati kot državljan«. Pri tem cilju posebej močno odstopamo od odgovorov, ki so jih dali strokovnjaki v drugih deželah ES. Ta cilj je najbolj odrinjen, ljudje si ne želijo več biti poučevani in se udeleževati takšnega družbenopolitičnega izobraževanja, kot se ga spominjajo izpred dveh desetletij. Verjetno tudi zato, ker jim je bilo tisto družbenopolitično izobraževanje pogostokrat vsiljeno in je pre- 


\begin{tabular}{|c|c|c|c|c|c|c|}
\hline \multirow[t]{2}{*}{ OHROCI } & \multicolumn{2}{|c|}{ rould } & \multicolumn{2}{|c|}{ N W ETICHO } & \multicolumn{2}{|c|}{ NOVACHE $/ 0$} \\
\hline & EV & SLO & EU. & S. & EU & 510 \\
\hline sporazumevati se & 5,9 & 5,8 & 5 & 4,9 & 61 & 71 \\
\hline acíli se kako se uctiti & 5,9 & 6 & 4,6 & 5,6 & 52 & 58 \\
\hline razvijati lastno osebnost & 5,8 & 6,2 & 4,5 & 4,9 & 45 & 63 \\
\hline sodelovati kot državljan & 5,8 & 4,5 & 4,3 & 3,8 & 43 & 23 \\
\hline družití se z ljudmi & 4,6 & 5,2 & 5,6 & 4,5 & 43 & 43 \\
\hline dajati smisel življenju & 5,4 & 6,1 & 4,1 & 5,2 & 30 & 34 \\
\hline izboljsati zaposlinivost & 5,3 & 5,5 & 4,3 & 4,9 & 52 & 55 \\
\hline vzdrževati zdravje, varnost & 5,1 & 5,7 & 3,8 & 4,1 & 35 & 40 \\
\hline sodelovati y kulturi & 5 & 4,8 & 3,8 & 4,1 & 33 & 18 \\
\hline $\begin{array}{l}\text { obvladovati dom in biti } \\
\text { odgovoren do družine }\end{array}$ & 4,9 & 5,7 & 3,3 & 4,1 & 20 & 16 \\
\hline uporabljati mat. in račun. & 4,6 & 5,2 & 4 & 4,6 & 52 & 61 \\
\hline
\end{tabular}

malo upoštevalo demokratično sodelovanje $\mathrm{v}$ izobraževalnem procesu pa tudi neposredne potrebe in interese udeležencev.

Ali torej to pomeni, da je »sodelovati kot državljan« najmanj pomemben cilj, da je to cilj, kjer je prav, da se najmanj zavzemamo, da zanemarimo inovacije v izobraževalnem pristopu?

Ali smemo področje demokratizacije družbe prepustiti stihiji in zanemariti tovrstno izobraževanje?

Katere pa so vsebine, ki so vendarle sprožile redke inovacije pri cilju sodelovati kot državljan? Odgovori: priprava novih programov za demokracijo ( 2 odg.), spoznavanje pravic in dolžnosti ( 2 odg.), razvoj večstrankarskega sistema ( 2 odg.), razvoj demokracije ( 2 odg.), državotvornost, odbori za materinski dom, za pediatrično kliniko, nova delavnica o socialnih veščinah.

Spremembe so bile spodbujene predvsem s spremembo politične situacije v Sloveniji ( 7 odg.), s potrebami ljudi v času prehoda, zaradi nemoči države, zaradi civilne pobude, zaradi slabega poznavanja lastne zgodovine, zaradi političnega zanimanja.

$V$ navedenih vsebinah (večstrankarski sistem, pravice in dolžnosti, razvoj demokracije, konkretne pobude za konkretno reševanje perečih družbenih problemov) bi kazalo zastaviti nove programe, upoštevati civilno pobudo in potrebo po poznavanju lastne zgodovine.

Tudi cilj sodelovati $v$ kulturi se kaže kot malo pomemben, zanj smo se sicer pripravljeni nekoliko bolj angažirati, vendar so bile inovacije v preteklosti precej redke. Temu cilju pripisujejo slovenski anketiranci precej manjši pomen kot kaže rezultat za celotni vzorec. Veliko vprašanje je, ali lahko razvijamo lastno osebnost in izboljšujemo medsebojno sporazumevanje, če puščamo sodelovanje v kulturi tako na stranskem tiru.

Na katere novosti glede vsebin pa se vendarle lahko opremo?

Anketiranci omenjajo: študijske krožke za razvoj kulture (3 odg.), študijski krožek za gledališče, obiske prireditev in razstav (3 odg.), pogovore in popularno kulturo (2 odg.).

Inovacije so bile spodbujene: s potrebo po novem, drugačnem, $\mathrm{s}$ potrebo po novi identifikaciji, $\mathrm{z}$ željo sodelovati $\mathrm{z}$ drugimi ljud$\mathrm{mi}$ (4 odg.), z željo popestriti izobraževalni program, dograjevati lastno dejavnost ali pa je inovacijo spodbudil izvajalec izobraževalnega programa.

Obvladovati dom in biti odgovoren za družino je prav tako cilj, kjer je bilo v zadnjih dveh letih malo inovacij. Kljub temu se anketiranim ta cilj ne zdi tako zelo nepomemben. Vendar posebnega angažiranja $v$ zadnjem času na tem področju izobraževanja odraslih ni bilo zaslediti.

Ali bo zaradi pomena družinske politike in majhnosti našega naroda vendarle potrebno spodbuditi inovacije pri izobraževanju za družino?
Anketiranci so navedli inovacije na naslednjih vsebinskih podrocjjih: učinkovito sporazumevanje, vodenje gospodinjstva, vzgoja otrok, družinsko-starševska predavanja, šola za življenje, poglabljanje v druge člane, igre vlog - otrok v meni, novi programi-delavnice, vsa področja doma in družine.

Spodbude so bile posledica »leta drư̌ine«, želje po boljšem razumevanju doma, upoštevanje interesa in potreb slušateljev (2 odg.), vodstva šol, večje moči krščanske demokracije pa tudi posledica slabe kakovosti družinskega življenja.

Inovacije so vzpodbudili tudi izleti in delovne akcije. Z letom družine ne bi smeli pozabiti na izobraževanje za družinsko življenje, seveda $z$ družino in na osnovi potreb, ki jih $v$ družinah ugotovimo. Želimo si lahko, da bo relativno visok pomen tega cilja spremljalo tudi angažiranje izobraževalcev, politikov, raziskovalcev in komentatorjev, da bi v maslednjih letih lahko zasledili tudi v okviru »družinskega« izobraževalnega cilja kaj več novosti.

\section{Evropske dimenzije}

Inovacije so pogosto povezane tudi $z$ idejami in izobraževalno dejavnostjo, ki prodira kot posledica gospodarskega in znanstvenega sodelovanja z Evropo. Koliko gre tukaj za enakopravno izmenjavo znanj in koliko za prenos novosti k nam, je vprašanje, ki ga naša raziskava ni zastavila.

Na osnovno vprašanje: Koliko ste osebno (ali vaše področje) soočeni s povezovanjem Evrope? so bili odgovori zelo obsežni. Največ odgovorov je bilo pri vprašanjih »know-how «, usposabljanju in razvijanju konceptov. To najbrž pomeni, da je tukaj več povezovanja kot pri razvijanju mrež, pridobivanju zaveznikov in financiranju.

Izmenjava »know-howak: $62,3 \%$ anketiranih ( $v$ celotnem vzorcu za EU 63\%) je na vprašanje opisno odgovorilo:

- povezovanje z univerzami (Velika Britanija, Nizozemska odprte univerze, Avstrija, Švedska, ZDA),

- z inštituti za izobraževanje odraslih (Italija, Anglija, Španija, Francija),

- s centrom za menedžment za Evropo (Bruselj),

- povezovanje s centri za raziskovanje in razvoj (Danska),

- s svetovalnimi inštitucijami, podjetji in partnerji (WIFI, Renault, PTT),

- s službami za zaposlovanje (Velika Britanija, Nemčija, Avstrija),

- v projektih PHARE, TEMPUS,

- $s$ tehnično akademijo v Esslingenu,

- v CEDEFOP, SVET EVROPE, ILO, ESREA, NCVQ, NEC, BOLDU, OLF, ILSCAE, OPWZ, EUROSTAT, ISATA, INNOVA, VHS (Nemčija),

$-\mathrm{z}$ bavarsko obrtno zbornico,

- z ustanovami za jezikovno izobraževanje (Belgija),

$-\mathrm{z}$ inštitutom za marketing (Finska).

Usposabljanje delavcev $(61,1 \%$ odgovorov za slovenski vzo$\mathrm{rec}$ in $38,5 \%$ za celotni vzorec EU):

- šolanje v okviru programa TEMPUS, PHARE,

- dobavitelji iz Francije, Nemčije, Italije,

- MBA Brdo,

$-z$ udeležbo na mednarodnih srečanjih ( 5 odg.),

- Alpe-Adria,

- Bavarska obrtna zbornica, INNOVA, OPWZ, REFA, 
$-\mathrm{z}$ univerzami (Velika Britanija in druge)

-s posamezniki (Holland, Reevies)

Glede na dokajšnjo razliko po številčnosti odgovorov bi lahko sklepali, da se naši strokovnjaki za izobraževanje odraslih pogosteje usposabljajo v tujini kot strokovnjaki iz drugih dežel.

Razvijanje skupne izobraževalne ponudbe (31,5\% odgovorov v slovenskem vzorcu in $42,5 \%$ v vzorcu EU).

Anketiranci dajejo podobne odgovore kot na prejšnje vprašanje, dodatno omenjajo še naslednje partnerje:

- ASA - American Society of Appraisers, Autodesk, CD6,

- razvijanje programa in učbenikov.

Razvijanje mrež $(24,1 \%$ odgovorov v slovenskem vzorcu in $45,6 \%$ odgovorov v vzorcu EU).

Glede na odgovore respondentov tudi pri razvijanju mrež nekoliko zaostajamo za strokovnjaki v evropski skupnosti. Naši strokovnjaki navajajo, da se povezujejo $\mathrm{v}$ naslednje mreže in organizacije:

- ESREA, INTERNET, PHARE, TEMPUS, elektronska pošta; univerzitetni profesorji, raziskovalci in podjetniki preko EFER,

$-\mathrm{s}$ svetovalci, inštituti in partnerji.

Pridobivanje zaveznikov in skupno predstavljanje $(22,2 \%$ je odgovorov v slovenskem in $23,5 \%$ v celotnem vzorcu).

Slovenski strokovnjaki za izobraževanje odraslih se skupaj predstavljajo in povezujejo svoje interese $\mathrm{z}$ naslednjimi organizacijami:

- ESREA, EAEA, UNESCO, INOVA, EBN, s Price Waterhouse, v okviru Alpe Jadran, z Evropskim združenjem, Svetovno konferenco »Rethinking Adult Education«, Lj. 93, State of Art Study.

Skupno razvijanje konceptov (31,5\% odgovorov v slovenskem vzorcu in $30,7 \%$ v celotnem vzorcu EU).

Poleg že navedenih zaveznikov, ki so jih navedli pri prejšnjem vprašanju, navajajo dodatno še skupno razvijanje konceptov: Wordperfect, jezikovna šola Berlitz.

\section{Finančno sodelovanje}

Med slovenskimi strokovnjaki je finančno sodelovanje potrdila več kot ena tretjina anketiranih $(38,2 \%)$, v celotnem vzorcu pa je finančnega sodelovanja manj ( $14,1 \%$ odgovorov). Slovenski strokovnjaki so navajali, da finančno sodelujejo $\mathrm{z}$ naslednjimi organizacijami oziroma projekti: UNESCO, ES, TEMPUS, PHARE, IHK, WIFI, Danish Demokratifont, Avstrija, Nemčija.

Druge oblike sodelovanja $z$ državami Evrope, ki so jih omenili slovenski strokovnjaki, so: skupne raziskave $\mathrm{z}$ državami Srednje in Vzhodne Evrope, s članstvom v EAIR, preko osebnih stikov z ljudmi (Nizozemska, Nemčija, Francija, Avstrija, Belgija).

Ponovni pregled odgovorov nakazuje, da se dokaj dobro vključujemo v dejavnosti evropskega povezovanja. Dobro je, da se naši strokovnjaki veliko usposabljajo v tujini (saj je slovenski prostor premajhen, da bi razvili kakovostno usposabljanje na vseh področjih izobraževanja odraslih), morda pa bi se to sodelovanje moralo bolj kazati tudi $\mathrm{v}$ poznejšem povezovanju (pri razvoju mrež, skupnih konceptov, izobraževalnih programov in skupnih nastopov).

$\mathrm{Na}$ »evropskem trgu izobraževalne ponudbe« smo najbrž še vse preveč v vlogi povpraševalcev po usposabljanju in finančnih sredstvih, premalo pa aktivno sodelujemo v procesih snovanja novih konceptov in skupne ponudbe.
Kakšno povezovanje na področju izobraževanja odraslih $v$ Evropi bi bilo dobro in zaželeno?

Anketiranci menijo, da bi bilo najbolj potrebno spodbuditi izmenjavo in usposabljanje strokovnjakov, skupno načrtovati raziskave in projekte ter uskladiti zakonodajo tako, da bi bili izobraževalni programi primerljivi. Navedimo odgovore:

- usposabljanje, izobraževanje in izmenjava strokovnjakov s poudarkom na sodobnih metodah ( $50 \mathrm{odg}$.),

- skupno načrtovanje raziskav, priprava skupnih programov, projektov (22 odg.),

- usklajevanje zakonodaje, primerljivost sistemov in programov, enotne klasifikacije poklicev (11 odg.),

- izmenjava študentov,

- skupni posveti, konference, revije in druge publikacije,

- povezovanje inštitucij glede na interese,

- srečanja in izmenjava izkušenj, npr. na področju tujega jezi$\mathrm{ka}$

- svetovalno, informacijsko in finančno povezovanje, terminološko usklajevanje,

- skupni programi za določene ciljne skupine, za splošno izobrazbo, osebnostni razvoj in državljansko vzgojo,

- razvijanje mrež, konceptov,

- svetovanje in povezovanje na področju poklicnega izobraževanja,

- povečati pretok kadra in omogočiti prihod tujega kapitala.

Odgovori strokovnjakov na celotnem vzorcu EU poudarjajo se potrebo po telekomunikacijah, potrebo po izmenjavi in obiskih v dobro razvitih izobraževalnih in raziskovalnih centrih, razvijanje izobraževanja za boljše razumevanje raznolikosti $v$ evropskih deželah ter spodbujanje koncepta vseživljenjskega izobraževanja.

Vodilno načelo evropskih oblasti na področju izobraževanja odraslih je načelo porazdeljene odgovornosti (subsidiarnosti). To pomeni, da se višje oblasti ne bi smele vmešavati v področja, $k i$ so domena nižjih. Kako si naši intervjuvanci razlagajo to načelo?

Eden izmed respondentov je odgovoril takole:

$\$ / . . . /$ kot uresničitev načela, da se stvari ne sme voditi birokratsko in centralistično, ampak je treba upoštevati pobude in ustvarjalnost tam, kjer se izobraževanje odraslih izvaja. Treba je s sorazmerno enotno sistemsko ureditvijo zagotoviti materialne in organizacijske možnosti za delo.«

$S$ tem načelom se večinoma strinjajo in poudarjajo, naj bi uspešnejši imeli več avtonomije, da je načelo porazdeljene odgovornosti povezano $s$ sodelovanjem vseh ravni in njihovo koordinacijo, gre torej za usklajeno delovanje od lokaine ravni do visjih.

Navajamo še nekaj razlag:

- Višje oblasti naj v grobem opredelijo cilje, principe in standarde za kakovost, nato naj nadzirajo izvajanje. Sicer naj bodo nižje oblasti vselej aktivno udeležene v vseh fazah.

- Potrebe naj izhajajo tudi iz prakse, iz nižjih ravni.

- To načelo naj bi pospeševalo ustvarjalnost in napredek na nižjih ravneh, večjo kakovost izobraževanja in motiviranost za izobraževanje odraslih.

Redki se $\mathrm{z}$ načelom ne strinjajo ( 3 od skupaj 50 odgovorov), saj menijo, da bi bilo to načelo lahko škodljivo, češ da v Sloveniji še nimamo dovolj urejene zakonodaje, drugi pa menijo, da smo 
premajhni za uveljavljanje tega načela, ali da bi se morali najprej spremeniti ljudje.

Kakšno politiko bi morale evropske oblasti izvajati na področju izobraževanja odraslih, ob upoštevanju katerih vidikov in ciljev ter pod kakšnimi pogoji? Kaj bi po vašem mnenju lahko storile evropske oblasti?

Največ predlogov se nanaša na poklicno izobraževanje mladih odraslih, sledi osnovno izobraževanje odraslih, študij na daljavo, potem poklicno strokovno izobraževanje odraslih in odprto visoko izobraževanje.

Najmanj predlogov je glede knjižnic, dramskega in umetnostnega izobraževanja, sociokulturne animacije in kmetijskega usposabljanja. Kot da so to manj pomembna področja v izobraževanju odraslih?

Ugotavljamo, da je med slovenskimi strokovnjaki za izobraževanje odraslih še vedno v ospredju razmišljanje o šolanju in poklicnem izobraževanju, s tem v zvezi zasledimo največ predlogov in pobud. Očitno je tudi vprašanje študija na daljavo že doseglo pomembno raven upoštevanja, kar najbrž pomeni pripravljenost za širšo uvedbo študija na daljavo.

Zbrali smo odgovore glede na vsebinsko ponudbo. Navajamo vsako posebej.

\section{Osnovno izobraževanje odraslih}

Osnovni cilji in vidiki so:

- dostopnost, masovnost in brezplačnost (13 odg.),

- dvig osnovne izobraženosti, dobra osnova ( 7 odg.),

- informiranost, jeziki, odprava nepismenosti, minimalna stopnja kvalifikacije, izmenjava izkušenj.

Med pogoji izstopajo:

- materialni pogoji, sredstva (12 odg., zato da bo brezplačno),

- enakopravnost z izobraževanjem odraslih (pogoji za udeležence),

- načrt, aktivna politika zaposlovanja in motivacijski pogoji.

\section{Poklicno izobraževanje mladih odraslih}

- Osnovni cilj poklicnega izobraževanja mladih naj bo prav tako dostopnost in prilagojenost potrebam (10 odg.),

- to naj bo priprava za poklic ( 9 odg.), omogoča naj zaposljivost, dvig poklicne izobraženosti, standardi naj bodo primerljivi (4 odg.), omogoča naj se prehodnost in izmenjava izkušenj. Pomembno je tudi znanje tujih jezikov.

Za dosego navedenih ciljev je potrebno:

- da je brezplačno, da je sofinancirano,

- imeti posebne ustanove, potrebno mrežo sol, razviti manj zahtevne programe,

- imeti enotno evropsko nomenklaturo poklicev,

- enotno zakonodajo,

- omogočiti mednarodno izmenjavo in odprtost navzven in navznoter.

\section{Poklicno/strokovno izobraževanje odrasih}

- Med cilji izstopa povezanost formalnega in neformalnega izobraževanja in težnja po nenehnem dvigu izobrazbe, po izpopolnjevanju, spremljanju razvoja za pretok in napredovanje,

- primerljivost programov, veljavnost in standardizacija spričeval, izmenjava študentov.

Pogoji za dosego navedenih ciljev:

- aktivna politika zaposlovanja,
- zakonodaja, sistemska urejenost in subvencioniranje (6 odg.),

- fleksibilnost oblik, ustrezni programi in ustrezni motivacijski dejavniki.

\section{Odprto visoko izobraževanje}

Cilji so zelo raznoliki:

- tehnološka opremljenost, ( 3 odg.), literatura,

-prepreciti beg možganov,

- privatizacija visokega šolstva,

- meddržavna mobinost, izmenjava študentov,

- študij na daljavo, enote po regijah, dobra razširjenost,

- interdisciplinarnost ( 1 odg.),

- motiviranje, večja dostopnost,

- upoštevati potrebe države.

Pogoji za dosego ciljev: poleg zakonodajnih, finančnih pogojev navajajo še sofinanciranja udeležencev, subvencije za revne, zahtevo po prehodnosti brez selekcije, sodelovanje univerz $\mathrm{s}$ stroko in prilagoditev našim dejanskim razmeram.

\section{Došolanje}

- Cilji in vidiki došolanja so podobni kot za strokovno izobraževanje; zajame naj čimveč ljudi ( 6 odg.), naj bo dostopno in prilagojeno potrebam. Omogoča naj prekvalifikacije in dokvalifikacije, zmanjšuje brezposelnost, omogoča izmenjavo izkušenj.

- Ustanoviti bi bilo potrebno enote po regijah ter $z$ medsebojnim priznavanjem spričeval omogočiti došolanje $\mathrm{v}$ drugih $\mathrm{dr}$ žavah.

Pogoji: enotni izobraževalni dopust, stimulacije delodajalcev, podpora države.

\section{Izobraževanje ob delu}

Med cilji izstopa potreba po večji dostopnosti, upoštevanje izkušenj, povezovanje izobraževanja in dela. Drugi vidiki so podobni kot za strokovno izobraževanje.

Pri pogojih moramo dodati še finančne, materialne pogoje, prav tako pa tudi povečati interes države, podjetij in posameznikov.

\section{Usposabljanje za obrt in trgovino}

Cilji in vidiki: celovito znanje in skrb za kupca, povezanost $\mathrm{s}$ prakso, certifikatni sistem, mednarodne izmenjave izkušenj, povezanost v društvih, organizacijah.

Pogoji: aktivna politika zaposlovanja, sistemska urejenost, kakovostni programi, širitev obrti, delovna mesta za prakso.

\section{Usposabljanje brezposelnih}

Osnovni cilj je povečati možnosti za zaposlitve ( 8 odg.), izboljšati, izmenjati oz. popestriti programe (nova znanja za samozavest, splošna izobrazba, izmenjava izkušenj), prilagoditi potrebam (države).

Pogoji: financiranje ( 3 odg.), več informacij, pomoč izkušenejših, prilagojenost vsebin potrebam, izobraževanje brezposelnih je obveznost.

\section{Kmetijsko usposabljanje}

Na prvem mestu je posodabljanje kot cilj, sledi zdrava pridelava hrane, popularizacija $v$ medijih, priprava krajših programov izpopolnjevanja, ekološko ozaveščanje in izmenjava izkư̌enj med državami (tudi z ekspertnimi skupinami).

Poleg državne pomoči (finančne) je potrebno prilagoditi vsebino ciljni skupini, upoštevati pomoč izkušenejših in imeti ustrezne predpise in zavest. 


\section{Sociokulturna animacija $v$ društvih}

Tukaj naštejmo nekaj predlogov: izstopa cilj dati novo kakovost življenju, s širino programov in dostopnostjo ponudbe - omogočiti druženje ljudi. Vodi naj k mednarodnemu povezovanju in na drugi strani $\mathrm{k}$ osebnostnemu razvoju posameznika.

Prvi pogoj je finančna stimulacija, izobraževanje naj temelji na prostovoljni udeležbi. Pogoj je tudi dvig kakovosti življenja in jezikovno znanje.

11. Sociokulturna animacija $v$ izobraževalnih centrih, akademijah...

Najpogostejši cilj je osebnostni razvoj posameznika, sledi izmenjava izkušenj, kultuma izmenjava, mednarodno povezovanje, šrša osebnostna kultura in nova kakovost življenja.

Pogoj za slednje je financiranje in izobraženi animatorji, interes, jezikovna znanja in podpora države.

12. Posebni izobraževalni projekti za posebne ciljne skupine

Cilji in vidiki: uvrstitev v nacionalni program, socializacija, doseganje avtonomnosti in razvoj duhovne človekove dimenzije, specifično za specifična okolja, sofinanciranje projektov, izdelana mreža organizacij, specializacija in potreba po mednarodni izmenjavi izkušenj.

Pogoji: zopet je na prvem mestu financiranje $\mathrm{z}$ javnimi sredstvi, dogovor med državama in inštitucijami, specialni programi, solanje izobraževalcev.

\section{Dramsko in umetnostno izobraževanje}

Cilji: osebnostni razvoj in višja kakovost življenja, povečati ponudbo, spodbuditi mobilnost študentov, izmenjava izkušenj in kulturno povezovanje.

Pogoji: podpora države, usposobljeni vodje, skupna ponudba kapacitet, mentorstvo, cas za udeležence, upoštevanje, tolerantnost, razvijanje želja.

\section{Izobraževalna televizija}

Med cilji je na pryem mestu »povečati ponudbo«, razviti mednarodne programe in povečati dostopnost (tudi s prevodi v slovenščno). Sledi ustreznost in sodobnost programa, priprava splošnoizobraževalnih oddaj, učenje in razvijanje strpnosti.

Pogoji: državno financiranje, dostopnost TV, kabelska TV (infrastruktura), prilagoditev specifičnostim države.

\section{5. Študij na daljavo}

Najpomembnejši cilj je pripraviti skupne programe, izmenjati dobre programe in subvencionirati prevode. Model izobraževan ja je potrebno prilagoditi slovenskim razmeram:

- urediti tehnično opremljenost, narediti dostopno vsakomur, pestri programi, ustrezna gradiva, upostevati osebnostni razvoj posameznika.

Pogoji: državno sofinanciranje; skupna priprava, mreža, didaktični paketi; šolanje izobraževalcev, pripravljenost na fakultetah.

\section{Knjižnice}

Cilji: ustanoviti multimedijske centre, povečati informiranost, odprtost in dostopnost, dati jim večjo izobraževalno vlogo (srečanja, svetovanje, organizirano samostojno učenje, prevodi, pomoč), mednarodno medknjižnično sodelovanje in izposoja.

Pogoji: državno sofinanciranje, več gradiva, kadrov in širine.

\section{Drugo}

Cilji: borza znanja, izmenjave.

Pogoji: državno sofinanciranje in mreža institucij.

Med cilji je najpomembnejša dostopnost in mednarodno sode- lovanje, pri pogojih pa je najpogosteje navedena nujnost državnega sofinanciranja.

Zastavimo si lahko vprašanje, koliko je smiselno za majhno državo, kot je Slovenija, posamezno vsebinsko ponudbo parcializirati. Ali ne bi bilo možno in smiselno v okviru konkretnega izobraževalnega programa oziroma področja zasledovati tudi še kakšno vsebinsko področje. Torej združevati, npr. uvajati sociokulturno animacijo $v$ osnovno in poklicno izobraževanje odraslih?

\section{Vprašanje začetne kvalifikacije}

V mnogih evropskih deželah razmišljajo o uvedbi začetne kvalifikacije. To pomeni, da bi si moral posameznik, preden se prvič zaposli, pridobiti vsaj najosnovnejši poklic. Hkrati naj ne bi zaposlovali oseb, ki še niso dopolnile 18 let. $\mathrm{V}$ izjemnih primerih, ko ta pogoj ne bi bil izpolnjen, naj bi bil delodajalec odgovoren, da bo poskrbel za usposobitev za prvi poklic.

Zaželenost uvedbe začetne kvalifikacije (Ali mislite, da bi moralo biti v Sloveniji doseganje začetne kvalifikacije uvedeno kot ukrep izobraževalne politike?)

Odgovori:

$D A(93,7 \%), N E(6,3 \%)$.

Tisti, ki so odgovorili z DA, navajajo naslednje utemeljitve:

- Začetna kvalifikacija bo prispevala k splošnemu razvoju ljudi $(93,2 \%)$.

- Norma za kvalifikacijo bi morala biti postavljena glede na jasno opredeljene temeljne zahteve $(86,8 \%)$.

- Pridobitev začetne kvalifikacije bo izboljšla zaposljivost slehemega državljana $(80,8 \%)$.

- Splošna izobrazba je najpomembnejši del začetne kvalifikacije $(77,8 \%)$.

- Začetna kvalifikacija bo okrepila gospodarstvo (72,5\%).

- Norma za kvalifikacijo bi morala biti postavljena glede na dano izobrazbeno raven $(65,2 \%)$.

- Tehnično-strokovne spretnosti so najpomembnejši del začetne kvalifikacije $(32,9 \%)$.

Možnosti za uveljavitev politike, $s$ katero se omogoči doseganje začetne kvalifikacije (Ali menite, da so v Sloveniji možnosti za uveljavitev začetne kvalifikacije?)

Večina odgovorov $(74,3 \%)$ je pritrdilnih. Sklicujejo se na velike potrebe za uveljavitev začetne kvalifikacije, ki bi se obrestovale tako pri reševanju osebnih kot tudi socialnih problemov. Anketiranci so napisali naslednje utemeljitve:

- To idejo je treba uresničiti tudi za odrasle, če želimo v korak s svetom.

- Za to idejo je treba prepričati tiste, ki imajo vpliv.

- To je dolgorođno cenejša in boljša rešitev, kot podpora brezposeinim, ki sedaj odhajajo $\mathrm{v}$ Avstrijo in Italijo. Po predlogu zakona o izobraževanju odraslih je začetna kvalifikacija uvrščena v nacionalni program. Potrebno je zajeti vse, ki niso uspešno zaključili osnovne šole.

Precej anketiranih je mnenja, da imamo v Sloveniji za uveljavitev začetne kvalifikacije ustrezne pogoje:

- splošno izobrazbeno raven, oprema v šolah omogoča dokvalifikacije, bruto narodni proizvod to omogoča, gre le za prerazporeditev, Slovenci se radi učimo, če vidimo v tem korist,

- nekaj programov je že narejenih (USO, CMO, UŽU),

- brezposelni imajo čas za izobraževanje,

- upoštevati bo treba andragoške principe, potrebna bo animacija, ne le prisila, 
- upad mladih generacij in razvita mreža šol.

Med pojasnili, da nimamo možnosti za uveljavitev politike za začetno kvalifikacijo (takšnih odgovorov je $25,7 \%$ ), so naslednji razlogi:

- ni ustreznih organov, programov,

- ne razmišljamo o tem, kakšne kadre potrebujemo, temveč izobražujemo nenačrtno,

- parlament še ni pripravljen, se ne zna opredeljevati do vprašanj izobraževanja odraslih,

- nizka ekonomska raven, možnosti priložnostnega zaslužka, izobrazba ni pogoj za zaposlitev,

- prisila ni dobra,

- vsaj pet let še ne,

- ni prostora in ni učiteljev.

$\mathrm{S}$ trditvijo, da je uveljavitev politike, s katero se omogoči doseganje začetne kvalifikacije, mogoča le v primeru, ce državne oblasti dajo pravno podlago zanjo, se strinja $90,7 \%$ vprašanih. $21,4 \%$ vpraSanih je za sankcioniranje tistih, ki si začetne kvalifikacije ne bodo pridobili. Ostali se s sankcioniranjem ne strinjajo. Za primerjavo navedimo, da se $\mathrm{v}$ celotnem vzorcu ES s sankcioniranjem strinja samo $15,8 \%$ anketiranih.

Čigava naj bo odgovornost za izvedbo takšnega ukrepa?

- državne oblasti $74,7 \%$

- delodajalcev $37,3 \%$

- drugo $27 \%$

Strokovnjaki za izobraževanje odraslih pred državne oblasti zelo jasno postavljajo pomembne zahteve, sprejeti bomo morali odločitve, ki nas bodo približale evropskemu sistemu in razmišljanju. Kot smo ugotavljali že po prvih analizah odgovorov (Krajnc, Večer, 17. junij 1995), slovenski respondenti od državnih oblasti zahtevajo več kontrole, postavljanja norm in sankcioniranja, kot velja to za anketirane v celotnem vzorcu v ES.

Seveda pa je zopet drugo vprašanje, ali o tem razmišlja civilna javnost in, ali bodo »komentatorji« sprožili dovolj široko medijsko razpravo o prihodnosti izobraževanja odraslih, da bo Slovenija pravočasno sprejela pomembne politične odločitve, ki bodo vplivale na razvoj izobraževanja odraslih.

\section{Sklep}

Po inovacijah, sproženih v izobraževanju odraslih, se Slovenija uvršč med tiste dežele, ki beležijo največ inovacij v zadnjih dveh letih. To si lahko razlagamo tudi s številnimi spremembami po osamosvojitvi Slovenije in spremembi političnega sistema. Odpiranje Slovenije je omogočilo, da smo dali večji poudarek izobraževanju odraslih, saj se zavedamo, da bomo le s spodbujanjem koncepta vseživljenjskega izobraževanja lahko sodelovali z Evropo. Sočasno so bili zastavljeni tudi kadrovski temelji za razvoj izobraževanja odraslih. Na Filozofski fakulteti so odprli visokošolski študij andragogike, ustanovljen je bil Andragoški center Republike Slovenije, ki se je v svojem kratkem obdobju hitro uveljavil prav s spodbujanjem inovativnosti v izobraževanju odraslih. Zaradi potreb po znanju so zrasle številne nove inštitucije in podjetja za izobraževanje odraslih.

Največ inovacij smo zasledili na področju komuniciranja (prav tako kot tudi v celotnem evropskem vzorcu), temu v slovenskem vzorcu sledi področje razvijanja lastne osebosti in uporabe računalniških znanj. V primerjavi $\mathrm{z}$ drugimi deželami je zaskrbljujoče malo inovacij pri cilju »sodelovati kot državljan«, kjer bo potrebno v prihodnje vložiti več naporov tudi za razvijanje potreb in primernih izobraževalnih programov.

Glede sodelovanja $z$ drugimi evropskimi deželami se v izobraževanju odraslih dokaj dobro povezujemo. Največ je sodelovanja pri izmenjavi "know-howa in usposabljanju zaposlenih, premalo pa je še skupne ponudbe in razvijanja mrež oziroma načrtnega dolgoročnega sodelovanja. Slovenski strokovnjaki za izobraževanje odraslih podpirajo načelo porazdeljene odgovornosti in zamisel o nujni začetni kvalifikaciji. Pri tem pa od državnih oblasti pričakujejo večjo mero odločnosti, nadzora in finančne podpore kot $v$ drugih evropskih deželah. Verjetno zato, ker smo bili v preteklih desetletjih navajeni, da je o izobraževanju odločala predvsem država, po drugi strani pa se nam mudi nadoknaditi zamujeno in zastaviti temelje za sistemsko urejanje izobraževanja odraslih, $\mathrm{ki}$ bo primerljivo $\mathrm{z}$ evropskimi trendi razvoja.

dr. Nena Mijoč

asistentka na Filozofski fakulteti v Ljubljani

\section{Literafura}

ABRAHAMSSON, Keneth: The Expanding Learning Enterprise in Sweden, Ministry of Education and Cultural Affairs, Swedish National Board of Education, 1990.

COURTNEY, Sean: Why Adults Learn, Routledge, London, 1992.

HARNSTEN, Gunilla: The Research Circle, Building Knowledge on Equal Terms, The Swedish Trade Union Confederation, Stockholm, 1994.

HUSEN, Torsten: The Learning Society, Richard Clay Ltd, Bungay, Suffolk, 1974.

JARVIS, Peter: Leaming, ageing and education in the risk society, $v$ Education and Ageing, The Beth Johnson Foundation, Staffordshire, Great Britain, 1994.

KRAJNC, Ana: Vloga izobraževanja odraslih pri demokratizaciji družbenih odnosov v Sloveniji, v zborniku prispevkov s posveta Vloga izobraževarja odrasilh pri demokratizaciji družbe, ADS, Ljubljana, 1995.

LEIRMAN, Walter: Eurodelphy, The Future Goals and Policies of Adult Education in Europe, Leuven, Belgium, 1995. 